INTUISI 12 (1) (2020)
INTUISI
JURNAL PSIKOLOGI ILMIAH
$\begin{gathered}\text { Ittp://journal.unnes.ac.id/nju/index.php/INTUISI } \\ \text { Terindeks DOAJ: 2541-2965 }\end{gathered}$

\title{
PERANCANGAN MOTION COMIC SEBAGAI MEDIA EDUKASI TENTANG KEPEDULIAN TERHADAP GANGGUAN KECEMASAN SOSIAL PADA REMAJA
}

\author{
Selvia $^{\bowtie}$, Jasson Prestiliano, T. Arie Setiawan Prasida
}

Program Studi Desain Komunikasi Visual, Fakultas Teknologi Informasi, Universitas Kristen Satya Wacana, Indonesia

\begin{tabular}{l}
\hline Info Artikel \\
\hline Sejarah Artikel: \\
Disubmit 3 Desember 2019 \\
Direvisi 24 Maret 2020 \\
Diterima 30 Maret 2020
\end{tabular}

\section{Keywords:}

Motion Comic, Social

Anxiety Disorder,

Educational Media

\begin{abstract}
Abstrak
Gangguan kecemasan sosial merupakan kondisi seseorang merasa cemas ketika berada di lingkungan sosial seperti takut menatap orang lain, takut diperhatikan di depan umum, dan takut akan penilaian yang diberikan orang lain. Gangguan ini kurang disadari oleh masyarakat, serta disadari sebagai masalah inheren dari suatu individu. Penelitian ini bertujuan untuk menyusun rancangan media motion comic sebagai edukasi tentang kepedulian terhadap gangguan kecemasan sosial agar dapat disadari oleh penderita dan orang disekitarnya sehingga dapat memperoleh treatment yang tepat. Metode penelitian yang digunakan adalah metode campuran. Proses penelitian diawali dengan memberikan kuesioner kepada 30 remaja kemudian dilakukan wawancara terhadap ahli psikologi, ahli komik, dan guru seni. Hasil perancangan berupa video komik bergerak mengenai penderita gangguan kecemasan sosial dan gejala yang muncul dengan beberapa tambahan efek suara. Hasil ulasan kepada ahli psikologi, ahli komik, guru seni, dan siswa sekolah menengah, menunjukkan bahwa perancangan motion comic mengenai edukasi tentang kepedulian terhadap gangguan kecemasan sosial untuk remaja ini sudah cukup baik. Media motion comic dapat menyampaikan pesan kepada target sebagai media edukasi tentang kepedulian terhadap seseorang yang mengalami gangguan kecemasan sosial.
\end{abstract}

\begin{abstract}
Social anxiety disorder is a condition of someone feeling anxious when in a social environment such as fear of staring at others, fear of being watched in public, and fear of judgment given by others. This disorder is less recognized by the community, and recognized as an inherent problem of an individual. This research aims to create a motion comic media as an education about caring for social anxiety disorder so that it can be realized by sufferers and those around them so they can get the right treatment. The research method in this study is mixed methods. Data collection technique started by giving questionnaires to 30 teenagers and conducted interviews with psychologists, a comic experts, and art teacher. The results of the design in the form of a moving comic video about people with social anxiety disorder and symptoms that appear with some additional sound effects. The results of the review to psychologists, comic experts, art teachers, and high school students, showed that the design of motion comics about education about caring for social anxiety disorder for adolescents was good enough. Motion comic as a media can deliver the message to the targeted participants as an educational tool to care for individuals with social anxiety disorder.
\end{abstract}

(C) 2020 Universitas Negeri Semarang

\footnotetext{
Alamat korespondensi:
}

Program Studi Desain Komunikasi Visual,

p-ISSN 2086-0803

Fakultas Teknologi Informasi, Universitas Kristen Satya Wacana e-ISSN 2541-2965 selvia274@gmail.com 


\section{PENDAHULUAN}

Gangguan

kecemasan sosial merupakan gangguan berupa ketakutan yang intens terhadap situasi sosial sehingga penderita menghadapinya dengan distres yang besar atau mungkin menghindarinya, hingga mengganggu aktivitas sehari-hari (Nevid, Rathus \& Greene, 2005). Penderita memiliki ketakutan berlebih terhadap evaluasi negatif dari orang lain, seolah-olah seribu pasang mata sedang memeriksa dengan teliti setiap gerakan yang mereka lakukan. Hal-hal seperti merasa takut, cemas, dan gugup saat berpikir bahwa orang lain akan menertawakannya di tempat umum, menghindari beraktifitas makan/minum di tempat umum, menghindari bertatapan langsung dengan orang lain, diikuti gejala fisik seperti wajah memerah, berkeringat, jantung berdebar, napas pendek, mual, gemetar, atau merasa pusing, merupakan gejala dari penderita gangguan kecemasan sosial (Nevid, Rathus \& Greene, 2005). Gangguan kecemasan sosial sangat lazim dalam populasi umum biasanya dimulai selama usia remaja dan secara signifikan mempengaruhi pencapaian pendidikan, upah yang buruk, hubungan keluarga yang buruk, meningkatkan risiko gangguan depresi, dan secara signifikan mengganggu kualitas hidup individu (Ratnani, et.al, 2017).

Berdasarkan Diagnostic and Statistical Manual of Mental Disorders (DSM V), fitur-fitur gangguan kecemasan sosial meliputi: rasa takut atau cemas yang ditandai tentang satu atau lebih situasi sosial di mana individu terpapar oleh pengawasan yang cermat oleh orang lain, seperti interaksi sosial (bercakap-cakap, bertemu orang yang tidak dikenal), diamati (saat makan atau minum), dan tampil di depan orang lain (memberikan pidato). Pada anak-anak, kecemasan harus terjadi dalam pengaturan teman sebaya dan tidak hanya selama interaksi dengan orang dewasa. Individu takut bahwa ia akan bertindak dengan cara atau menunjukkan gejala kecemasan yang akan dievaluasi secara negatif. Situasi sosial hampir selalu memancing rasa takut atau kecemasan, dihindari atau ditanggung dengan ketakutan atau kecemasan yang intens. Ketakutan, kecemasan, atau penghindaran menyebabkan tekanan atau gangguan signifikan secara sosial dalam bidang sosial, pekerjaan, atau bidang fungsi penting lainnya (National Center for Biotechnology Information, 2016).

Fobia sosial atau disebut juga sebagai gangguan kecemasan sosial bermula pada masa anak dan remaja (Nevid, Rathus \& Greene, 2005). Hal ini juga dipengaruhi oleh psikologi perkembangan pada masa remaja yang memiliki ciri-ciri kejiwaan tidak stabil, keadaan emosinya mudah goncang, peka, mudah tersinggung, dan perhatiannya terpusat pada dirinya. Perkembangan kehidupan sosial remaja juga ditandai dengan gejala meningkatnya pengaruh teman sebaya dalam kehidupan remaja. Bagi sebagian remaja, ditolak atau diabaikan oleh teman sebaya menyebabkan munculnya perasaan kesepian atau permusuhan hingga masalah kesehatan mental dan kejahatan (Desmita, 2017). Gangguan kecemasan sosial yang terjadi pada remaja berusia 9 hingga 17 tahun diperkirakan 10\% hingga 20\% (Joshi, et.al, 2013). Sebesar $70 \%$ hingga $95 \%$ remaja membisu dengan hanya memilih berbicara pada situasi tertentu ketika dihadapkan pada situasi sosial, itu merupakan bentuk kecemasan sosial yang ekstrim pada remaja (Rachmawaty, 2015). Sebuah penelitian berjudul Mengatasi Kecemasan Sosial Melalui Pendekatan Behavioral Rehearsal, tertarik membahas gangguan kecemasan sosial, dengan target yang sama yaitu remaja, mengenai strategi mengatasi kecemasan sosial pada siswa dalam memainkan peran terhadap situasi yang dianggapnya dapat menimbulkan kecemasan agar dapat berinteraksi dan memiliki penyesuaian dilingkungan sekolah (Saman, Aryani, \& Bakhtiar, 2017).

Masyarakat jarang menyadari fobia sosial karena sering dianggap sebagai 
introvert, pemalu, atau pribadi yang anti sosial (Tiffany, 2017). Gangguan kecemasan sosial adalah kondisi kejiwaan yang melemahkan yang dapat disembuhkan, namun seringkali tidak terdeteksi dan tidak diobati. Prevalensi kecemasan sosial di kalangan remaja sekolah bervariasi dari satu negara ke negara. Misalnya, di negara-negara berpenghasilan tinggi, besarnya berkisar antara 3,5\% hingga 21\%. Meskipun ada kelangkaan bukti di negara-negara berkembang, literatur yang tersedia menunjukkan bahwa gangguan kecemasan sosial lebih tinggi, yang berkisar antara 10,3\% hingga 27\% (Mekuria, et.al, 2017). Prevalensi gangguan kecemasan sosial kurang dipelajari di masyarakat Timur dan dilaporkan sangat kurang $0,4 \% \quad-0,6 \%$ di negara-negara Asia Tenggara (Ratnani, et.al, 2017).

Gangguan kecemasan sosial juga dapat memberi dampak negatif yang mempengaruhi kehidupan sehari-hari. Penderita social anxiety disorder menghadapi hambatan internal dan eksternal dalam mengakses perawatan kesehatan mental. Hambatan internal adalah hasil dari gangguan itu sendiri, jika seseorang sudah merasa cemas atau berpikir mengenai stigmatisasi tentang mencari perawatan kesehatan mental, kekhawatiran yang meningkat tentang melakukan atau mengatakan sesuatu yang memalukan akan membuat hambatan untuk mencari perawatan menjadi lebih besar. Hambatan eksternal adalah kurangnya kesadaran akan gangguan di antara orangorang yang mengalami social anxiety disorder (Pollack \& Mark, 2018). Lingkungan sekitar memiliki dampak yang signifikan terhadap kesehatan mental di mana tekanan rutin kehidupan sehari-hari dapat menyebabkan dan memperkuat perasaan cemas. Merancang ruang publik dengan pola pikir kesehatan mental yang positif setidaknya menjadi salah satu bagian dari solusi.

Berdasarkan teori bahwa lingkungan memiliki dampak terhadap penderita gangguan kecemasan sosial, terdapat data mengenai perilaku responden remaja terhadap penderita gangguan kecemasan sosial. Data ini diambil dari 30 responden remaja perempuan dan laki-laki berusia 13-18 tahun melalui kuesioner mengenai apa yang akan dilakukan apabila responden memiliki teman yang memiliki gejala perilaku gangguan kecemasan sosial seperti merasa takut, cemas, dan gugup saat berpikir bahwa orang lain akan menertawakannya di tempat umum, menghindari beraktifitas makan/minum di tempat umum, menghindari bertatapan langsung dengan orang lain. Dengan pernyataan-pernyataan seperti pada Tabel 1 .

Tabel 1

Hasil Kuesioner Responden Tentang Pendapatnya terhadap Penderita Gangguan Kecemasan Sosial

\begin{tabular}{llcccc}
\multicolumn{1}{c}{ Pernyataan } & SS & S & RR & KS & TS \\
\hline 1. Teman yang berperilaku seperti itu adalah wajar atau & 2 & 22 & 3 & 3 & 0 \\
normal & & & & \\
2. Teman yang berperilaku seperti itu hanya bersifat pemalu & 3 & 16 & 6 & 5 & 0 \\
3. Teman yang berperilaku seperti itu berkepribadian aneh & 0 & 2 & 9 & 10 & 9 \\
4. Teman yang berperilaku seperti itu merupakan introvert & 3 & 8 & 13 & 4 & 2 \\
$\quad \begin{array}{l}\text { atau anti sosial } \\
\text { 5. Wajar atau normal bila memilikiperilaku seperti itu }\end{array}$ & 2 & 18 & 7 & 2 & 1 \\
6. Perlu berkonsultasi dengan psikolog jika memiliki perilaku & 0 & 0 & 12 & 14 & 4 \\
\hline
\end{tabular}


Hasil jawaban dari kuesioner pada Tabel 1 menunjukkan bahwa gejala social anxiety masih kurang disadari karena dianggap normal atau wajar, serta dianggap hanya bersikap pemalu. Responden juga merasa tidak perlu berkonsultasi dengan psikolog apabila memiliki gejala seperti itu, hal ini merupakan salah satu hambatan bagi penderita untuk mencari pertolongan. Pada kuesioner juga terdapat pertanyaan mengenai apakah responden mengetahui gangguan kecemasan sosial, ternyata hanya 11 dari 30 orang yang pernah mendengar mengenai gangguan kecemasan sosial, 15 orang mengaku belum pernah dan 4 mengaku tidak tahu. Hal tersebut menunjukkan kurangnya informasi yang dapat mengedukasi remaja lebih dalam mengenai gangguan kecemasna sosial sehingga membuat remaja tidak menyadari gejala perilaku yang terdapat pada dirinya dan teman disekitarnya. Data ini memperkuat dukungan perlu dibuatnya motion comic sebagai media edukasi terhadap gangguan kecemasan sosial pada remaja.

Motion comic dipilih sebagai media karena cocok sebagai media edukasi. Motion comic menjadi sebuah daya tarik baru memahami materi pembelajaran. Pembelajaran dengan motion comic, apalagi diusia mereka sangat dekat dengan fasilitas yang mendukung dalam menyaksikan motion comic, yaitu melalui telepon genggam dan komputer yang sudah tidak menjadi barang mewah disaat ini, menjadi faktor utama penambahan media pembelajaran baru dalam dunia pendidikan (Gunawan, 2019). Sebuah penelitian juga menggunakan motion comic untuk menyampaikan pesan mengenai human immunodeficiency virus (HIV) dan sexually transmitted diseases (STD). Penelitian tersebut mengungkapkan hasil bahwa motion comic adalah metode yang dapat diterima untuk menyampaikan pesan pencegahan HIV melalui plot dan latar cerita yang menarik dan menghibur. Motion comic dianggap sebagai metode baru yang layak untuk menyampaikan pesan komunikasi masalah kesehatan masyarakat (Willis, et.al, 2018). Sebuah studi lain juga menggunakan media yang tepat untuk menyampaikan pesan kepada generasi muda khususnya anak-anak dan remaja, tentang cerita pewayangan melalui media visual yang dibalut dengan moderenisasi seperti motion comic (Saptodewo, 2015). Temuan dari studi terdahulu ini mendorong penelitian kali ini untuk mengkaji motion comic lebih lanjut.

Motion comic merupakan gabungan antara komik dan pergerakan animasi yang terbatas (limited animation). Animasi sederhana ini dibuat dengan permainan layer per layer, dengan gerakan yang tidak banyak seperti gerak ke kiri atau ke kanan, serta zoom in atau zoom out. Motion comic juga memiliki narasi maupun backsound sehingga dapat memberikan suasana yang unik dan berbeda kepada pembaca (Maharsi, 2018). Media motion comic dapat memberikan pembaharuan presentasi yang tidak hanya melalui visual melainkan terdapat limited animation didalamnya, sehingga semakin menarik dan digemari pembaca, terlebih dengan kemudahan aksesnya yang bisa melalui world wide web (Maharsi, 2018). Motion comic memberi lebih banyak imajinasi kepada pembaca. Smith (2015) menggambarkan bahwa motion comic dapat saling mempengaruhi dan menyatukan antara komik, animasi dan media interaktif (Idris, 2016).

Media motion comic ini digunakan karena biasanya anak usia remaja suka membaca komik, motion atau gerak dalam bentuk video ditambahkan agar lebih interaktif serta lebih menarik. Adapun penambahan instrumen lain seperti musik latar berupa efek-efek suara yang dapat mempermainkan psikologis sehingga penonton bisa lebih merasakan bagaimana rasa takut yang dirasakan oleh penderita gangguan kecemasan sosial. Narasi visual, seperti komik dan animasi, menjadi semakin 
populer sebagai alat untuk pendidikan dan komunikasi. Menggabungkan manfaat visualisasi dengan metafora yang kuat dan narasi berbasis karakter, komik memiliki potensi untuk membuat subjek ilmiah lebih mudah diakses dan menarik bagi khalayak yang lebih luas (Farinella, 2018).

Penelitian ini dilakukan untuk merancang motion comic tentang kepedulian terhadap gangguan kecemasan sosial serta mengetahui bagaimana respon dari responden setelah melihat motion comic tersebut. Tujuan dari penelitian ini adalah untuk merancang media edukasi berupa motion comic bagi remaja agar lebih memahami mengenai gangguan kecemasan sosial. Penelitian ini memiliki manfaat untuk menciptakan kepedulian sosial untuk menyadari gejala perilaku dari penderita kecemasan sosial dan memperlakukan orang dengan gangguan kecemasan sosial dengan tepat. Gangguan kecemasan sosial biasanya mulai muncul selama masa remaja, dan puncak onsetnya adalah pada umur sekitar 15 tahun (Durand \& Barlow, 2006). Oleh sebab itu, usia remaja sekitar 13-18 tahun merupakan target penting dalam penelitian ini, karena merupakan usia yang sangat rentan mengalami gangguan kecemasan sosial.

Peneliti tidak menggunakan penelitian eksperimental dalam penelitian ini karena tanggapan responden melalui kuesioner dirasa cukup untuk mengetahui apakah hasil perancangan motion comic sudah menyampaikan pesan dengan baik atau belum sebagai sebuah media edukasi. Pengujian motion comic dilakukan secara mixed methods dengan mendapatkan data gabungan dari wawancara kepada ahli dan kuesioner untuk mengetahui respon dari responden yang melihat hasil video motion comic mengenai gangguan kecemasan sosial tersebut.

\section{METODE}

Metode penelitian yang digunakan pada penelitian ini adalah metode campuran (mixed methods). Metode penelitian campuran (Mixed Methods) adalah jenis penelitian di mana peneliti atau tim peneliti menggabungkan unsur-unsur pendekatan penelitian kualitatif dan kuantitatif (mis., Penggunaan sudut pandang kualitatif dan kuantitatif, pengumpulan data, analisis) (Schoonenboom \& Johnson, 2017). Tujuan keseluruhan dari penelitian metode campuran, menggabungkan komponen penelitian kualitatif dan kuantitatif, adalah untuk memperluas dan memperkuat kesimpulan penelitian dan berkontribusi untuk menjawab pertanyaan penelitian (Schoonenboom \& Johnson, 2017). Metode campuran yang digunakan dalam penelitian ini mencakup beragam fitur untuk mencapai banyaknya partisipan, menentukan keberhasilan dan relevansi konteks kepada target remaja dengan perhitungan kuantitatif respon remaja melalui kuesioner, dan membandingkan berbagai perspektif dengan data kualitatif yang didapatkan dari wawancara kepada ahli mengenai hasil perancangan penelitian.

Strategi yang digunakan dalam perancangan motion comic ini adalah cyclic strategy. Cyclic strategy atau strategi berputar ini pada dasarnya sama dengan linear strategy, hanya saja pada strategi ini ada kalanya suatu tahap perlu diulang kembali untuk menampung umpan balik (feedback) sebelum tahap berikutnya dilanjutkan. Perulangan tahap ini disebut loop. Ada kalanya terdapat dua atau lebih loop yang terkandung dalam satu loop yang lebih besar (Sarwono, 2007). Penelitian ini menggunakan beberapa variabel yang diukur mengenai kelayakan motion comic sebagai media edukasi tentang gangguan kecemasan sosial untuk remaja yaitu variabel desain, animasi, dan motion comic sebagai media edukasi. Definisi operasional dari perancangan motion comic tentang gangguan kecemasan sosial ini adalah desain yang diterapkan dalam motion comic berupa warna ilustrasi, ekspresi, dan jenis font; animasi yang diterapkan dalam 
motion comic berupa alur, gerakan animasi, durasi, suara latar (backsound), dan efek suara (sound effect); dan motion comic sebagai media edukasi untuk menyampaikan pesan serta memberikan dampak respon remaja terhadap gangguan kecemasan sosial. Variable tersebut kemudian dijabarkan menjadi pernyataan kuesioner yang diujikan kepada responden dan diukur menggunakan skala Likert dengan 4 gradasi score yaitu sangat setuju (4), setuju (3), kurang setuju (2), dan tidak setuju (1).

Pada perancangan motion comic ini, ada lima tahapan yang dilakukan yaitu pengumpulan data dari target dan ahli, analisis data menjadi konsep perancangan, tahap perancangan motion comic mulai dari pembuatan ilustrasi dan proses editing, evaluasi dari ahli kemudian melakukan revisi sesuai masukan dari para ahli, dan terkahir hasil perancangan yang diujikan kepada target remaja dan guru. Tahapan yang berulang pada proses perancangan ini ada pada tahapan perancangan dan evaluasi, yaitu jika pada evaluasi terdapat revisi dari para ahli, maka proses akan kembali pada tahap perancangan untuk merancang kembali hasil motion comic sesuai dengan masukan dari para ahli. Tahapan untuk perancangan motion comic tentang gangguan kecemasan sosial untuk anak remaja dapat dilihat pada Gambar 1 . Bagian metode akan menjelaskan tahapan perancangan media motion comic.

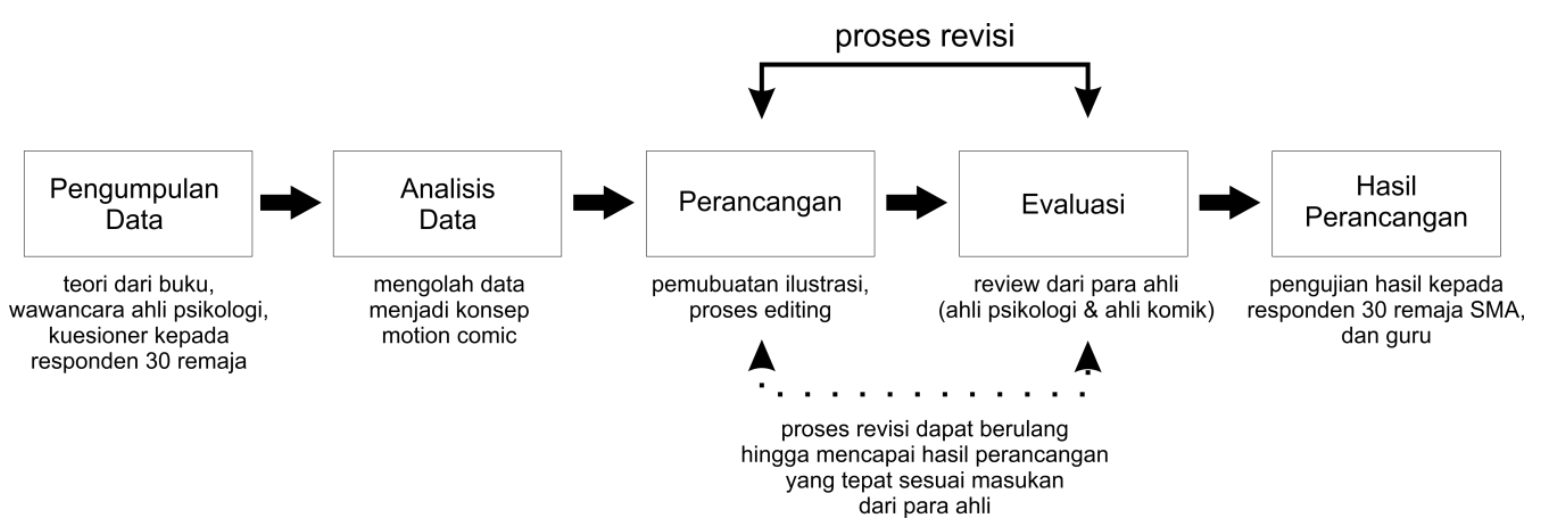

Gambar 1. Tahapan Perancangan Motion Comic tentang Gangguan Kecemasan Sosial [Sumber: Selvia]

Terdapat beberapa partisipan dalam penelitian ini yaitu ahli psikologi, ahli komik, guru seni, dan 30 remaja usia 13-18 tahun. Pengambilan data melalui para ahli dilakukan secara wawancara langsung, sementara pengambilan data guru dan remaja dilakukan melalui kuesioner. Tujuan dari mewawancarai ahli psikologi dan ahli komik adalah untuk mengetahui kelayakan konten dan desain motion comic. Tujuan dari pengambilan data kepada guru dan remaja adalah untuk menguji media motion comic apakah sudah baik dalam menyampaikan pesan mengenai edukasi terhadap gangguan kecemasan sosial kepada remaja. Tahap awal dari penelitian ini adalah pengumpulan data. Pengumpulan data dilakukan dengan mengkaji dari buku yang terkait dengan topik, memperhatikan penelitian yang sudah ada. Data yang dicari berupa data mengenai gangguan kecemasan sosial, psikologi perkembangan masa remaja, motion comic, dan proses pembuatannya.

$$
\text { Penulis melakukan wawancara }
$$

kepada seorang psikolog klinis yang memahami tentang gejala-gejala gangguan kecemasan sosial. Narasumber tersebut menyarankan untuk melihat buku-buku mengenai psikologi abnormal yang mengacu pada DSM V. Sementara mengenai pengaruh lingkungan sosial terhadap penderita 
gangguan kecemasan sosial, narasumber menyatakan bahwa lingkungan sosial berpengaruh terhadap penderita gangguan kecemasan sosial, dengan persoalan apabila semakin banyak orang yang mengerti dan memiliki wawasan mengenai gangguan kecemasan sosial, maka orang-orang akan dapat bersikap atau memberikan treatment yang lebih tepat terhadap penderita gangguan kecemasan sosial.

Tahap berikutnya, merupakan tahap perancangan motion comic. Perancangan ini terdiri dari tiga proses yaitu pra-produksi, produksi, dan pasca produksi. Pada praproduksi dilakukan pembuatan ide konsep menjadi sebuah alur cerita pada motion comic mengenai gejala gangguan kecemasan sosial. Konsep yang ingin dihadirkan adalah bagaimana membuat target paham mengenai apa itu social anxiety disorder melalui gejala intinya yaitu merasa cemas ketika berbicara dengan orang lain, merasa seolah-olah banyak orang memperhatikannya, merasa ditertawakan, dan takut akan penilaian orang lain. Diikuti gejala fisik seperti gemetar, mual, jantung berdebar, dan wajah memerah sebagai gejala fisik yang biasa dirasakan penderita gangguan kecemasan sosial. Kecemasan pikiran penderita (tokoh utama dalam motion comic) divisualisasikan dalam bentuk bayangannya serta bentuk verbal dari kalimat dalam pikirannya. Cerita motion comic ini juga ingin memperlihatkan bagaimana kepedulian teman yang seharusnya diterapkan terhadap anak penderita gangguan kecemasan sosial dan bagaimana seorang penderita kecemasan sosial melepaskan dirinya dari pikiran-pikirannya sendiri akan penilaian orang lain. Konsep tersebut kemudian diolah menjadi beberapa scene dalam bentuk storyboard pada Gambar 2, sebagai acuan dalam pembuatan motion comic.

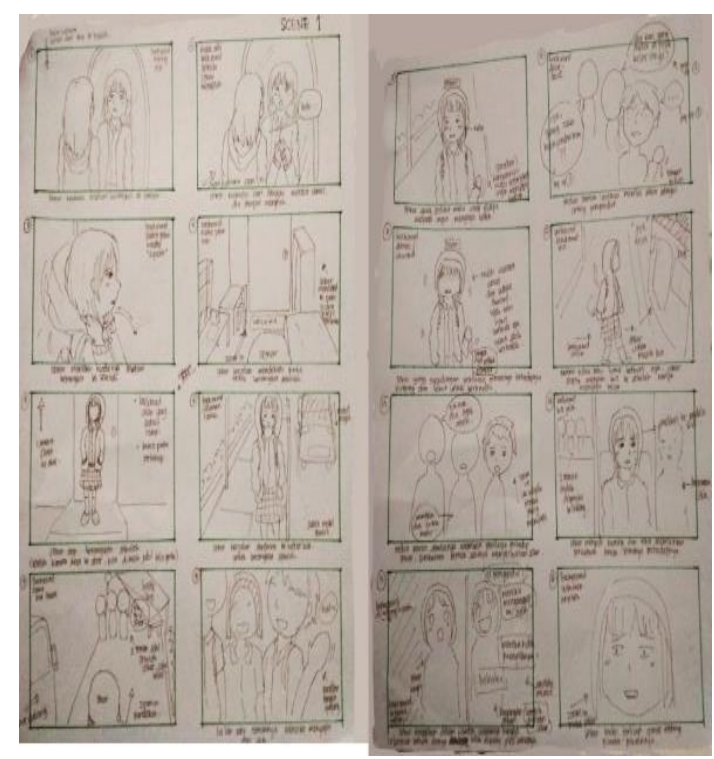

Gambar 2. Storyboard Perancangan Motion Comic tentang Gangguan Kecemasan Sosial [Sumber: Selvia]

Proses produksi diawali dengan membuat ilustrasi karakter, background, dan gelembung kata. Beberapa desain ilustrasi dan gelembung kata sebagai bentuk percakapan di motion comic dibuat per layer yang memisahkan antara foreground dengan background untuk menyesuaikan dengan proses pemberian motion pada background, foreground, maupun pada saat berdialog dan gelembung kata muncul. Sementara beberapa ilustrasi lainnya yang hanya digerakkan secara zoom in atau zoom out dibuat flat menyatu agar memudahkan dalam proses editing. Gambar 3, menjelaskan bagaimana rupa sketsa karakter dan ilustrasi background. 

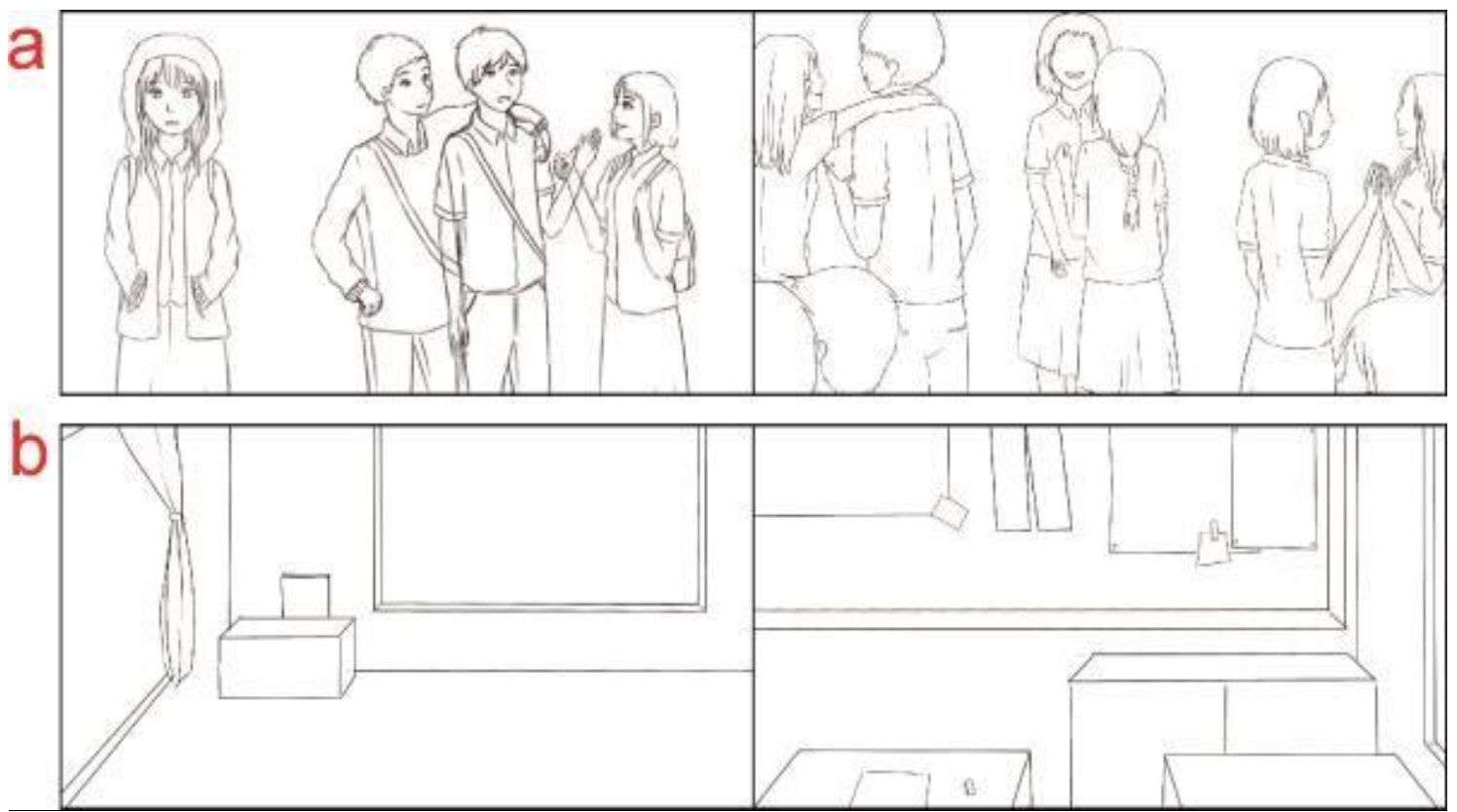

Gambar 3. Sketsa Karakter (A) dan Sketsa Background (B)

[Sumber: Selvia]

Teks pada Gambar 4, yang digunakan dalam pembuatan motion comic ini adalah tipografi jenis Komika. Penggunaan tipografi Komika ini cocok digunakan sebagai dialog dalam komik karena termasuk tipografi sans serif. Font Sans-Serif cenderung digunakan untuk hal-hal yang semi formal, santai dan sangat sesuai apabila digunakan dalam digital. Sans Serif dinilai membawa kekuatan, kejelasan, tampilan bersih dan modern ke dalam desain (International Design School, 2018).

\section{ABCDEFGHIJKLMNOPQRSTUWWXYZ abcdefghijklmnopqrstuvwxyz 1234567890?!}

Gambar 4. Text Komika untuk Tipografi dalam Komik

[Sumber: Selvia]

Ilustrasi yang sudah jadi akan diberikan motion animasi sederhana berupa zoom in, zoom out, panning, fade in, fade out, efek parallax, dan pergerakan bagian karakter, kemudian disatukan dengan kemunculan gelembung kata pada setiap momen dialognya ke dalam timeline yang pas
(Gambar 5). Pemberian audio latar menjadi tahap terakhir dari proses produksi melalui proses mixing sesuai adegan yang ada di dalam motion comic. Pada proses ini, semua materi perancangan dijadikan satu menjadi sebuah video motion comic. 


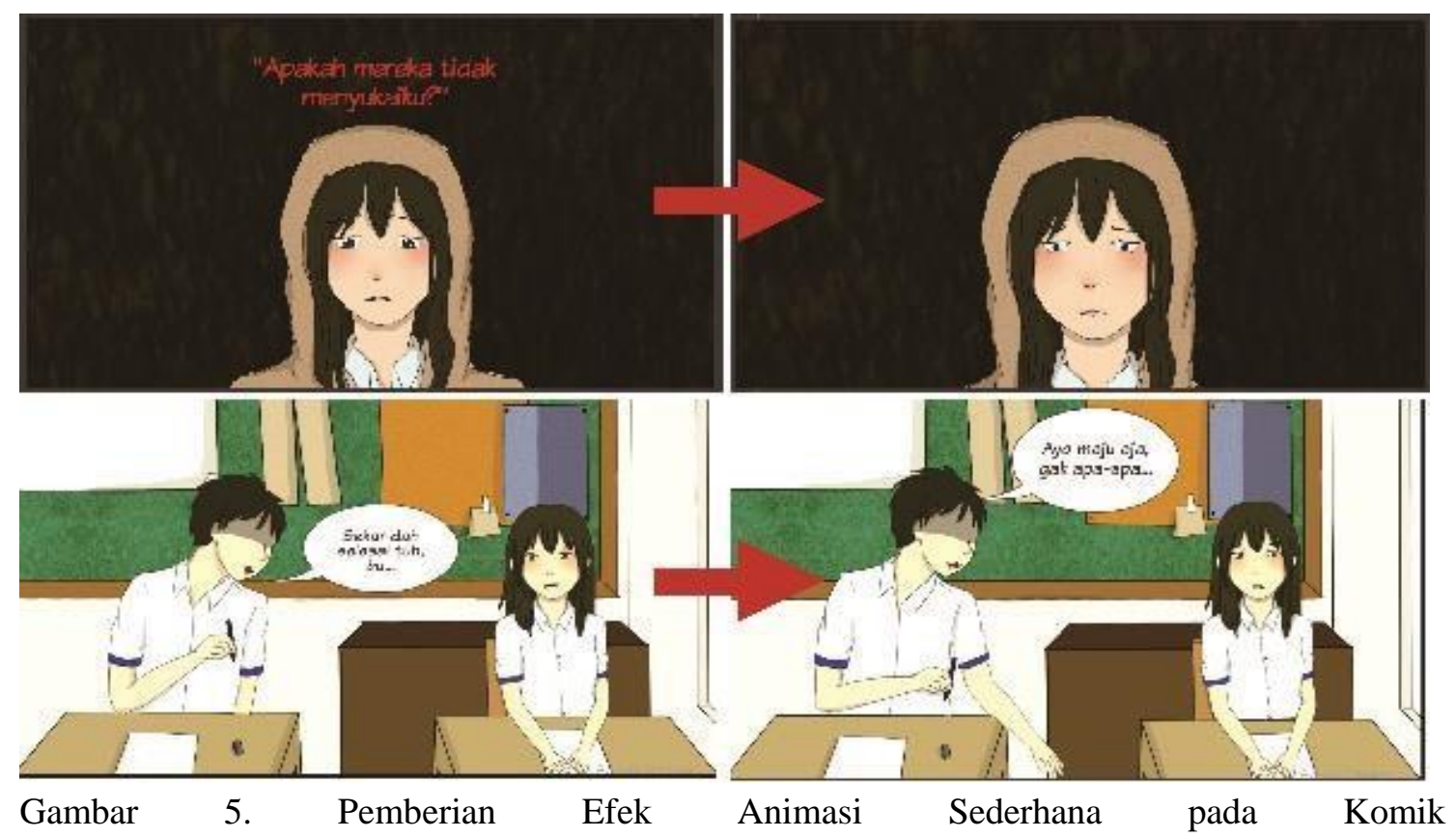

[Sumber: Selvia]

Setelah proses perancangan selesai, media motion comic akan di review oleh ahli psikologi dan ahli komik melalui wawancara untuk pengambilan data kualitatif mengenai ketepatan konten dan desain. Hasil video motion comic juga akan diuji kepada guru seni dan sejumlah siswa sekolah menengah atas untuk mendapatkan data kuantitatif mengenai kecakapan motion comic dalam menyampaikan pesan sebagai media edukasi terhadap gangguan kecemasan sosial kepada remaja melalui kuesioner.

\section{HASIL DAN PEMBAHASAN}

Berdasarkan analisis data dan perancangan yang telah dilakukan terdapat hasil berupa video motion komik yang bercerita mengenai seorang anak yang mengalami gangguan kecemasan sosial, pengaruh lingkungan sebayanya terhadap penderita, dan perubahan pola pikir penderita agar tidak merasa cemas lagi. Kecemasan anak tersebut digambarkan melalui pemikirannya sendiri terhadap pendapat orang lain tentangnya.
Video motion comic menggunakan resolusi 1280 x 720 px dengan durasi 8 menit ini merupakan komik bergerak dengan tambahan sound effect dan suara latar untuk menambah suasana bagaimana seorang penderita gangguan kecemasan sosial merasakan kecemasannya yang sebenarnya adalah bentuk dari pikiran dia sendiri. Gerakan animasi pada motion comic menggunakan fps (frame per second) yang lebih rendah yaitu $15 \mathrm{fps}$ dari pada fps video pada umunya (24 fps), untuk menghasilkan pergerakan animasi yang limited.

Hasil perancangan pertama merupakan pembuatan illustrasi karakter yang akan digunakan dalam motion comic. Pada Gambar 6, beberapa karakter utama akan memiliki warna sementara karakter background yang bertujuan untuk melengkapi suasana hanya akan berwarna abu-abu. Tokoh utama dalam motion comic ini adalah seorang anak perempuan yang menderita gangguan kecemasan sosial bernama Sekar, serta beberapa teman sekelasnya. 


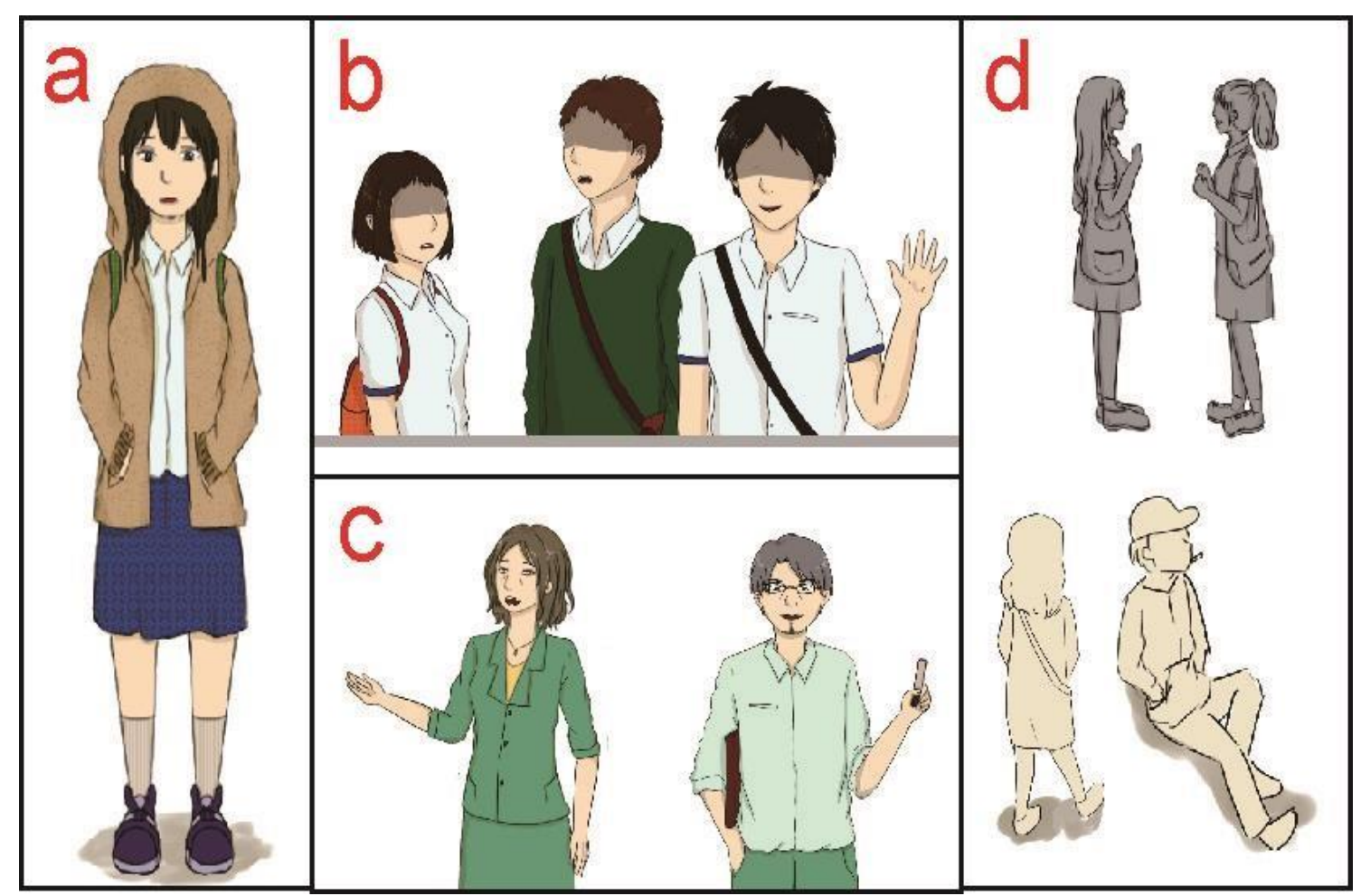

Gambar 6. Desain Karakter Sekar (A), Teman Sekelas (B), Guru (C), dan Karakter Latar Pendukung (D)

[Sumber: Selvia]

Hasil perancangan selanjutnya, lingkungan sekitar sebagai penambah suasana memuat background dan foreground yang digambar secara terpisah tiap layer (Gambar 7). Background berupa latar tempat yang akan digunakan di dalam scene motion comic, sementara foreground berupa bagian dari dalam motion comic. Terdapat background hitam sebagai penanda munculnya kecemasan dalam pikiran karakter Sekar. Ada pula gambar flat yang hanya digerakan secara panning maupun zoom in atau zoom out.

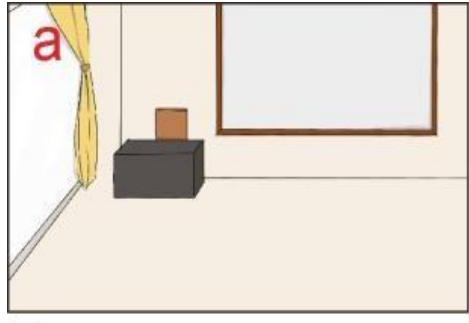

b

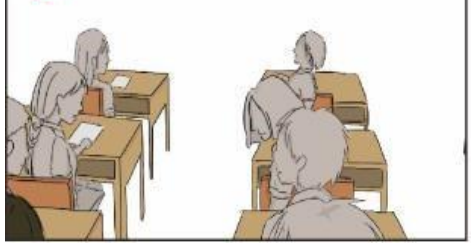

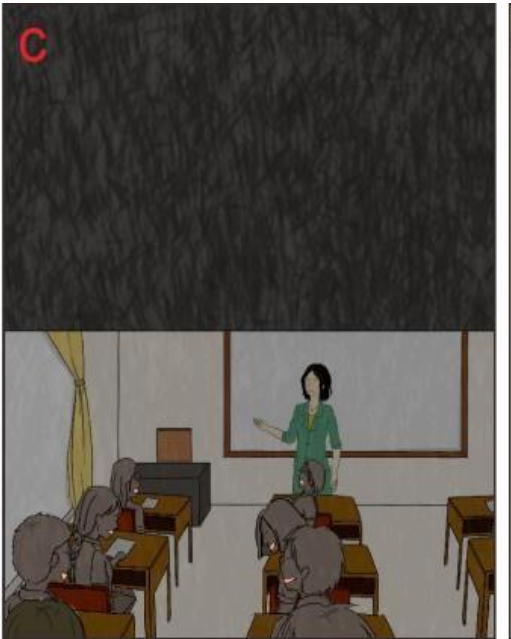

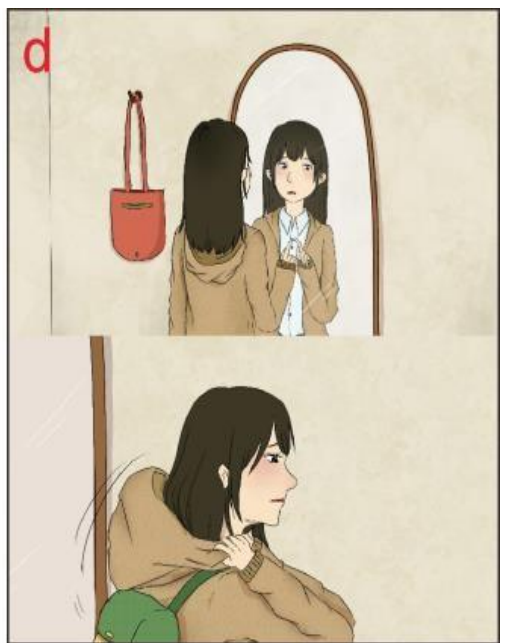

Gambar 7. Background Kelas (a), Foreground Murid (b), Background dengan Tone Hitam (c), dan Gambar Flat (d)

[Sumber: Selvia] 
Produksi motion comic ini juga menggunakan teks dalam gelembung kata sebagai pengungkapan dialog dalam komik, dapat dilihat pada Gambar 8. Penggunaan gelembung kata hanya akan muncul pada timeline tertentu saat karakternya saling berbicara. Pada saat karakter utama berbicara dalam pikirannya sendiri, dialognya hanya berupa tulisan biasa yang tidak disertai gelembung kata.

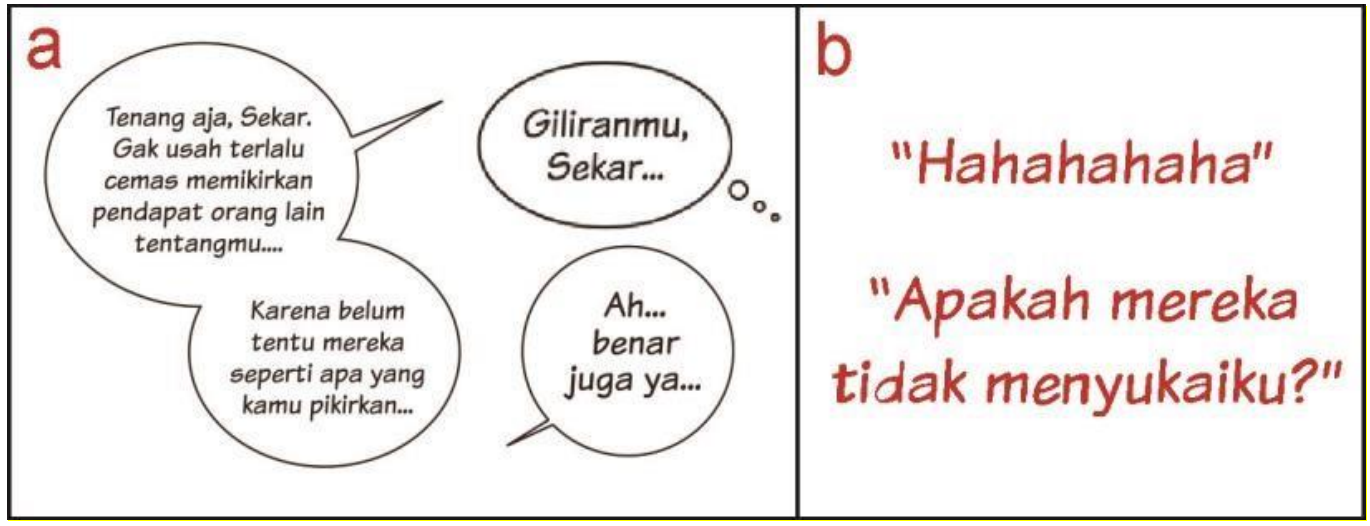

Gambar 8. Gelembung Kata (a) dan Kata Tanpa Gelembung (b)

[Sumber: Selvia]

Selanjutnya terdapat proses pemberian sound effect dan audio latar yang disesuaikan dengan suasana dalam motion comic untuk memberikan kesan suasana komik yang lebih hidup. Setelah proses mixing audio selesai, maka semua scene motion comic akan dijadikan satu dan diberi
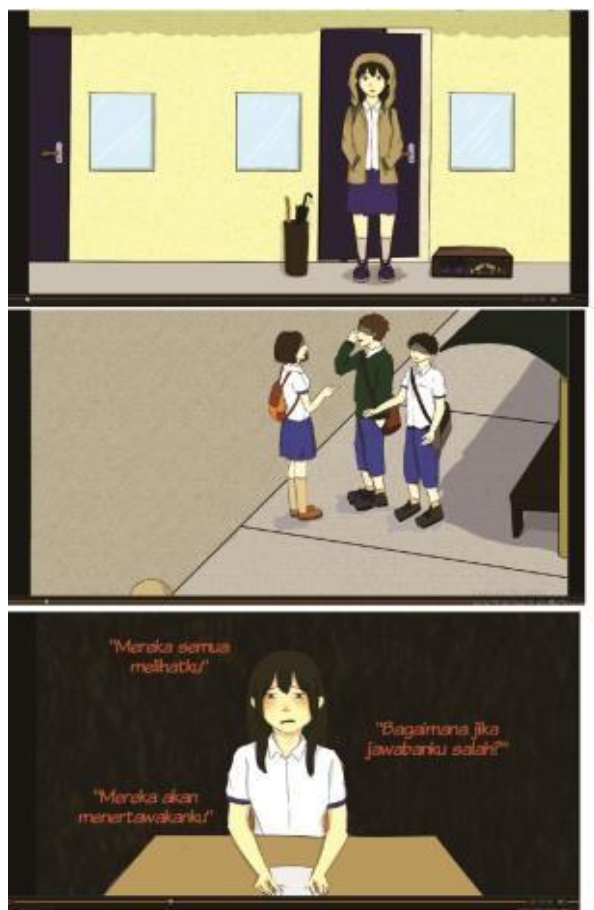

Gambar 9. Tampilan Hasil Motion Comic

[Sumber: Selvia] grading untuk menyesuaikan warna dari semua scene yang telah dibuat. Tampilan hasil motion comic, pergerakan, dan kemunculan teks, dapat dilihat pada Gambar 9. Video motion comic juga telah diupload ke Youtube agar dapat disaksikan secara online.

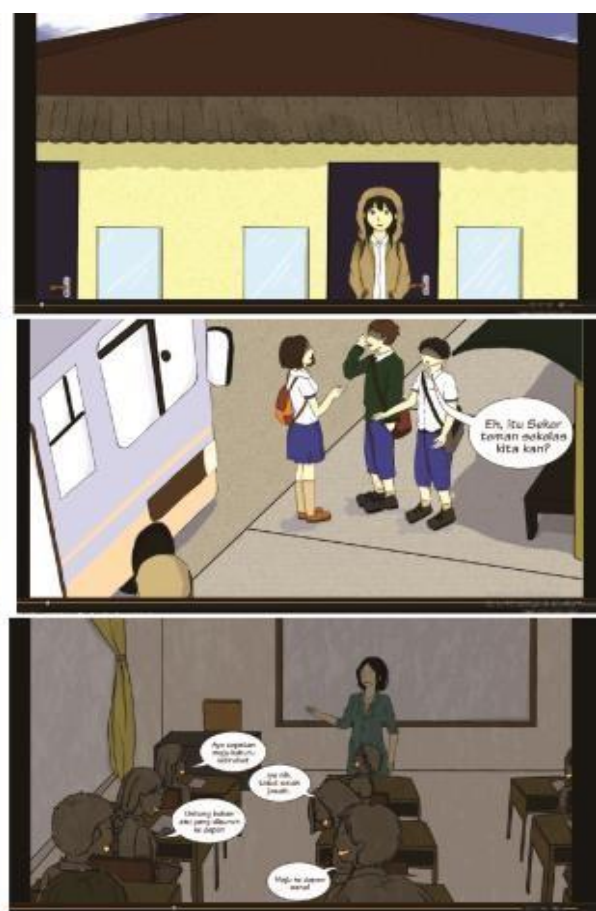


Hasil motion comic tersebut kemudian dikonsultasikan kepada ahli psikologi klinis. Pengambilan data kepada ahli psikologi dilakukan melalui wawancara langsung pada tanggal 20 November 2019. Berikut pernyataan ahli psikologi ketika ditanya mengenai pendapatnya setelah video motion comic tentang gangguan kecemasan sosial:

"Konsep ceritanya sih sudah bagus. Dari awal sampai akhir, saya lihat sudah menyampaikan cerita. Ada gejala dari bagaimana si karakter utama merasakan gangguan kecemasannya, kemudian sampai akhir bahwa temannya yang peduli itu memberikan treatment yang tepat sehingga si tokoh utama itu menjadi lebih baik. Dalam hal ini sudah menyampaikan gangguan kecemasan sosial secara uтит ya, kalau tujuannya sebagai memperkenalkan gangguan kecemasan sosial kepada lingkungan sebayanya. Apalagi kalau untuk remaja, saya kira cocok ya dengan komik, dan latar cerita disekolah seperti itu." (Ibu WK, 20 November 2020).

Dari pernyataan tersebut, dapat diinterpretasikan bahwa pendapat ahli psikologi mengenai konsep cerita dan penyampaian pesan melalui motion comic sudah cukup baik menggambarkan tentang gangguan kecemasan sosial secara umum pada remaja.

Terdapat juga saran dari ahli psikolgi terhadap video motion comic mengenai gangguan kecemasan sosial ini:

"Menurut saya (ekspresi karakter) tidak (seram) sih. Ini sudah menggambarkan bagaimana dia itu takut. Mungkin backsoundnya ya dirubah suasananya dari pada suara ditertawakan, diganti suara yang lebih mengejek seperti hииииии gitu. Lalu dibagian scene ini, saya lihat ada beberapa kata 'mungkin aku tidak bisa' nah itu diganti saja jadi 'aku pasti tidak bisa' karena penderita kecemasan sosial itu biasanya udah berpikir bahwa dirinya itu gak bisa. Ini akan memberikan kesan lebih judgemental kepada kondisi tokoh utama sebagai penderita." (Ibu WK, 20 November 2020).

Dari pernyataan tersebut, dapat diinterpretasikan bahwa ahli psikologi memberi saran mengenai dampak penyampaian psikologi pada beberapa bagian ekspresi dan backsound yang mungkin terkesan seram, diubah menjadi terkesan mengejek. Penggunaan verbal pada komik diubah menjadi lebih tajam. Contohnya, kata "mungkin aku tidak bisa" diubah menjadi "aku pasti tidak bisa" sehingga dapat menyampaikan perasaan yang dirasakan oleh penderita gangguan kecemasan sosial yang diceritakan di dalam motion comic.

Kikuatama selaku komikus webtoon official yang pernah mengangkat tema mental disorder pada komiknya berjudul Ghost's Dilemma, juga telah memberikan review terhadap perancangan motion comic ini. Pengambilan data respon dari ahli komik tersebut dilakukan dengan cara wawancara tidak lansung yaitu melalui jalur daring pada tanggal 22 januari 2020. Berikut pernyataan ahli komik ketika ditanya mengenai pendapatnya setelah video motion comic tentang gangguan kecemasan sosial:

"Sebagai seorang komikus yang juga pernah menggarap karya dengan tema yang sama: mental disorder, saya suka dengan karyamu yang mengangkat tema ini. Animasinya sudah lumayan bagus, lagu yang digunakan juga sudah sesuai dengan mood yang ditonjolkan dalam adegan yang terjadi. Plot dan moral value yang ingin di sampaikan cukup jelas tergambar dari animasi tersebut. Adegan favorit saya jelas ada di ending animasi, dimana perasaan 
karakter utama tersampaikan dengan jelas dengan musik yang sangat cocok dengan flow adegan: sehingga menciptakan atmosfir yang 'indah'." (Kikuatama, 22 Januari 2020).

Dari pernyataan tersebut, dapat diinterpretasikan bahwa ahli komik menganggap animasi yang digunakan cukup bagus, backsound sesuai dengan mood dalam adegan, serta plot dan moral value yang ingin disampaikan cukup jelas.

Ahli komik juga memberikan saran terhadap perancangan motion comic sebagai berikut:

"Masukan dari saya, mungkin author bisa meningkatkan impact dari cerita tersebut melalui penggambaran adegan yang lebih sedikit dramatis, coba buat beberapa adegan di mana karakter utama merasa anxious lewat sudut pandangnya: misalnya waktu awal ia) bercermin, daripada penggambaran karakter hampir full-body dalam adegan, scene take bisa di-zoom lebih dekat pada karakter. Psychologic-wise biasanya karakter dengan mental disorder kecemasan yang parah, cenderung takut melihat wajah orang lain; inipun bisa menjadi masukan dalam pembuatan scene: misalnya ketika awal karakter utama bertemu dengan laki-laki dan teman-temannya, ia berani melihat muka laki-laki itu karena cukup kenal, tapi wajah kedua orang temannya tidak diperlihatkan (digelapkan), di mana kemudian sewaktu si karakter utama sadar dari dukungan si laki-laki akhirnya penggambaran teman si laki-laki ini diperjelas untuk bisa menambah kesan dramatis. Kelam yang dirasakan oleh si karakter utama ini bisa di twist oleh dukungan laki-laki itu. Dimana lewat penggambaran adegan ini juga dapat memperkuat impact dari plot dan moral value yang ingin disampaikan oleh author." (Kikuatama, 22 Januari 2020).

Pernyataan ahli komik tersebut dapat diinterpretasikan bahwa ahli komik memberi saran untuk meningkatkan impact dari adegan komik. Penggambaran wajah tokoh disekitar karakter utama yang dibuat lebih misterius diawal, dengan maksud bahwa penderita kecemasan sosial biasanya tidak berani memandang lawan bicaranya, hingga kemudian diakhir cerita wajah misterius itu lebih terungkap untuk menunjukkan bahwa karakter tokoh utama sudah lebih berani membuka dirinya terhadap orang lain disekitarnya, serta menambah zoom-in pada adegan tertentu, agar lebih fokus terhadap ekspresi karakter.

Berdasarkan hasil wawancara terhadap para ahli, didapatkan kesimpulan bahwa hasil perancangan motion comic sebagai media edukasi tentang kepedulian terhadap gangguan kecemasan sosial untuk remaja ini sudah cukup baik. Pesan yang disampaikan melalui cerita pada motion comic sudah menggambarkan gangguan kecemasan sosial secara umum. Ahli psikologi memberikan saran mengenai dampak psikologis dari adegan komik melalui verbal yang dibuat lebih tajam dan backsound dirubah menjadi berkesan mengejek, agar suasana gangguan kecemasan dalam komik dapat lebih tersampaikan. Ahli komik memberikan saran mengenai hal teknis dalam pembuatan komik agar bisa menyampaikan impact dari adegan, melalui zoom scene dan penggambaran karakter lain dari sudut pandang tokoh utama. Penulis melakukan proses revisi terhadap motion comic berdasarkan saran dari ahli sebelum melakukan pengujian hasil motion comic kepada remaja selaku target audience.

Penulis kemudian menunjukkan motion comic tersebut kepada guru seni dan 30 siswa-siswi SMA di Salatiga. Guru Seni 
suatu SMA di Salatiga juga melakukan review terhadap motion comic tersebut. Menurutnya, hasil perancangan motion comic sudah menyampaikan pesan dengan baik mengenai gejala gangguan kecemasan sosial dan kepedulian terhadap penderita melalui alur animasi disertai lagu latar dan efek suara yang sesuai dengan suasana cerita. Hasil respon dari guru seni dapat dilihat pada Tabel 2.

Tabel 2

Hasil Respon Guru Seni mengenai Motion Comic tentang Gangguan Kecemasan Sosial

\begin{tabular}{|c|c|c|c|c|}
\hline Pernyataan & SS & $S$ & $\mathrm{KS}$ & TS \\
\hline Desain karakter dalam motion komik menarik & $\mathrm{V}$ & & & \\
\hline Ekspresi karakter sudah sesuai dengan suasana cerita & & & $\mathrm{v}$ & \\
\hline $\begin{array}{l}\text { Alur dapat dipahami dan durasi adegan pada video motion komik } \\
\text { sudah sesuai dengan adegan yang digambarkan }\end{array}$ & $\mathrm{V}$ & & & \\
\hline $\begin{array}{l}\text { Lagu pengiring (backsound) dan efek suara yang digunakan dalam } \\
\text { video motion komik sudah sesuai dengan suasana cerita }\end{array}$ & $\mathrm{V}$ & & & \\
\hline $\begin{array}{l}\text { Video motion komik ini merupakan sarana edukasi yang informatif } \\
\text { mengenai gangguan kecemasan sosial. }\end{array}$ & $\mathrm{v}$ & & & \\
\hline $\begin{array}{l}\text { Video motion komik ini menjelaskan dengan baik mengenai gejala } \\
\text { seseorang yang memiliki gangguan kecemasan sosial. }\end{array}$ & & $\mathrm{V}$ & & \\
\hline $\begin{array}{l}\text { Pesan yang disampaikan melalui video motion komik ini dapat } \\
\text { diterima dengan baik oleh para siswa. }\end{array}$ & $\mathrm{V}$ & & & \\
\hline $\begin{array}{l}\text { Melalui video motion komik ini, pesan untuk mempedulikan teman } \\
\text { yang memiliki gangguan kecemasan sosial, sudah tersampaikan. }\end{array}$ & $\mathrm{v}$ & & & \\
\hline $\begin{array}{l}\text { Melalui video motion komik ini, pesan untuk tidak berpikiran cemas } \\
\text { mengenai apa yang orang lain pikirkan tentang diri kita, agar } \\
\text { terhindar dari gangguan kecemasan sosial, sudah tersampaikan. }\end{array}$ & $\mathrm{v}$ & & & \\
\hline $\begin{array}{l}\text { Setelah melihat video motion komik ini, saya akan menggunakan } \\
\text { video motion komik ini sebagai media pembelajaran untuk memberi } \\
\text { edukasi mengenai gangguan kecemasan sosial kepada siswa/i. }\end{array}$ & & $\mathrm{v}$ & & \\
\hline
\end{tabular}

Desain dan ilustrasi dalam motion comic sudah dianggap baik, hanya saja perlu adanya penguatan ekspresi pada karakter pendukung yang lebih diperlihatkan, sedangkan karakter utama seharusnya dikaburkan ekspresinya: "Ekspresi tokoh utama sebaiknya dikaburkan (ekspresi tokoh yang takut terlihat) dan teman-teman dari tokoh utama yang ekspresinya harus dikuatkan." (Respon tertulis Bapak S, 6 Februari 2020). Hal ini mejadi sebuah kontra dari pendapat ahli komik yang menyatakan bahwa ekspresi karakter pendukung seharusnya diburamkan karena tokoh utama sebagai penderita gangguang kecemasan sosial memiliki gejala takut untuk menatap wajah orang lain, sehingga ekspresi lebih terfokus untuk karakter utama untuk menunjukkan gejala kecemasan sosial yang dialami karakter.

Motion comic mendapat respon melalui kuesioner kepada 30 siswa-siswi SMA di Salatiga dengan jumlah 19 pernyataan yang kuesioner mengenai variable desain, animasi, dan motion comic sebagai media edukasi untuk mengukur kelayakan motion comic sebagai media edukasi tentang kepedulian terhadap gangguan kecemasan sosial untuk remaja. Hasil perhitungan kuesioner dapat dilihat pada Tabel 3. 
Tabel 3

Hasil Kuesioner Persetujuan Responden tentang Hasil Perancangan Motion Comic

\begin{tabular}{|c|c|c|c|c|c|c|}
\hline Pernyataan & SS & S & $\mathrm{KS}$ & $\mathrm{TS}$ & $\begin{array}{c}\text { Hasil } \\
(\%)\end{array}$ & $\begin{array}{c}\text { Kategori Skala } \\
\text { Pernyataan }\end{array}$ \\
\hline $\begin{array}{l}\text { Desain karakter dalam motion komik } \\
\text { menarik }\end{array}$ & 6 & 20 & 4 & 0 & 76.67 & Sangat Setuju \\
\hline $\begin{array}{l}\text { Ekspresi karakter sudah sesuai dengan } \\
\text { suasana cerita }\end{array}$ & 7 & 20 & 2 & 1 & 77.5 & Sangat Setuju \\
\hline $\begin{array}{l}\text { Warna yang digunakan pada illustrasi } \\
\text { sudah baik }\end{array}$ & 6 & 22 & 2 & 0 & 78.33 & Sangat Setuju \\
\hline $\begin{array}{l}\text { Warna yang digunakan pada background } \\
\text { sudah menggambarkan suasana dengan } \\
\text { baik }\end{array}$ & 11 & 15 & 4 & 0 & 80.83 & Sangat Setuju \\
\hline $\begin{array}{l}\text { Warna yang digunakan pada tulisan sudah } \\
\text { baik sehingga dapat dibaca dengan jelas }\end{array}$ & 13 & 17 & 0 & 0 & 85.83 & Sangat Setuju \\
\hline $\begin{array}{l}\text { Jenis tulisan / teks yang digunakan dapat } \\
\text { dibaca dengan baik }\end{array}$ & 16 & 14 & 0 & 0 & 88.33 & Sangat Setuju \\
\hline $\begin{array}{l}\text { Durasi munculnya tulisan / teks sesuai } \\
\text { dengan waktu untuk membaca }\end{array}$ & 14 & 16 & 0 & 0 & 86.67 & Sangat Setuju \\
\hline Alur animasi dapat dipahami dengan baik & 8 & 17 & 5 & 0 & 77.5 & Sangat Setuju \\
\hline Gerakan animasi pada karakter sudah baik & 3 & 15 & 11 & 1 & 66.67 & Setuju \\
\hline $\begin{array}{l}\text { Gerakan animasi pada transisi antar } \\
\text { adegan sudah baik }\end{array}$ & 6 & 18 & 6 & 0 & 75 & Setuju \\
\hline $\begin{array}{l}\text { Durasi adegan pada video motion comic } \\
\text { sudah sesuai dengan adegan yang } \\
\text { digambarkan }\end{array}$ & 9 & 19 & 2 & 0 & 80.83 & Sangat Setuju \\
\hline $\begin{array}{l}\text { Lagu pengiring atau backsound yang } \\
\text { digunakan sesuai dengan suasana cerita }\end{array}$ & 11 & 16 & 3 & 0 & 81.67 & Sangat Setuju \\
\hline $\begin{array}{l}\text { Efek suara yang digunakan sudah tepat } \\
\text { dengan adegan yang digambarkan }\end{array}$ & 6 & 22 & 2 & 0 & 78.33 & Sangat Setuju \\
\hline $\begin{array}{l}\text { Sebelum melihat video motion comic ini, } \\
\text { saya belum mengerti tentang apa itu } \\
\text { gangguan kecemasan sosial }\end{array}$ & 6 & 13 & 8 & 3 & 68.33 & Setuju \\
\hline $\begin{array}{l}\text { Sesudah menonton video motion comic } \\
\text { ini, saya jadi mengetahui atau lebih } \\
\text { mengerti mengenai apa itu gangguan } \\
\text { kecemasan sosial. }\end{array}$ & 12 & 18 & 0 & 0 & 85 & Sangat Setuju \\
\hline $\begin{array}{l}\text { Video motion comic ini menjelaskan } \\
\text { dengan baik mengenai gejala seseorang } \\
\text { yang memiliki gangguan kecemasan } \\
\text { sosial. }\end{array}$ & 10 & 20 & 0 & 0 & 83.33 & Sangat Setuju \\
\hline $\begin{array}{l}\text { Setelah melihat video motion comic ini, } \\
\text { saya akan mempedulikan teman yang } \\
\text { memiliki gejala gangguan kecemasan } \\
\text { sosial seperti karakter dalam komik. }\end{array}$ & 11 & 18 & 0 & 1 & 82.5 & Sangat Setuju \\
\hline $\begin{array}{l}\text { Setelah melihat video motion comic ini, } \\
\text { saya akan mengurangi untuk berpikir } \\
\text { cemas mengenai apa yang orang lain } \\
\text { pikirkan tentang diri saya, agar terhindar } \\
\text { dari gangguan kecemasan sosial. }\end{array}$ & 12 & 17 & 1 & 0 & 84.17 & Sangat Setuju \\
\hline $\begin{array}{l}\text { Setelah melihat video motion comic ini, } \\
\text { saya mau mengajak teman / orang lain } \\
\text { untuk menontonnya, agar memiliki } \\
\text { edukasi mengenai gangguan kecemasan } \\
\text { sosial. }\end{array}$ & 9 & 20 & 1 & 0 & 81.67 & Sangat Setuju \\
\hline
\end{tabular}


Perhitungan skala Likert yang didapatkan cukup positif. Rata-rata presentase hasil pernyataan diatas $75 \%$ yang menunjukkan bahwa video motion comic tersebut dapat diterima dengan baik sebagai media edukasi mengenai gangguan kecemasan sosial. Hal tersebut ditunjukkan dengan hasil uji variable penelitian yang cukup baik yaitu kategori kelayakan desain pada pernyataan kuesioner mengenai motion comic mendapat respon sebesar 82.09\%, kelayakan animasi pada motion comic mendapat respon sebesar $76.67 \%$, serta kelayakan motion comic sebagai media edukasi mencapai $80.83 \%$ respon baik dari seluruh responden. Perincian respon dari responden terhadap variabel penelitian dapat dilihat melalui Tabel 4.

Tabel 4

Hasil Respon Responden terhadap Desain Motion Comic, Animasi Motion Comic, dan Motion Comic sebagai Media Edukasi

\begin{tabular}{ll}
\hline \multicolumn{1}{c}{ Kategori Variabel } & Hasil \\
\hline 1. Desain & $82.09 \%$ \\
2. Animasi & $76.67 \%$ \\
3. Media Edukasi & $80.83 \%$ \\
\hline
\end{tabular}

Hasil penelitian berupa motion comic ini dapat menjadi media dalam pendidikan psikologi bagi remaja untuk meningkatkan kepedulian terhadap penderita gangguan kecemasan sosial. Guru seni dari sekolah tersebut juga mendukung perancangan motion comic ini sebagai media edukasi yang baik mengenai gangguan kecemasan sosial dengan respon setuju untuk menjadikannya sebagai media pembelajaran kepada siswa-siswi. Adapun beberapa keterbatasan dalam penelitian ini adalah kurangnya waktu dalam masa produksi motion comic dikarenakan proses pengecekan kepada ahli yang dilakukan berkali-kali hingga revisi perancangan sesuai dengan hasil yang diinginkan, serta keterbatasan ilmu psikologi yang dipakai dalam penelitian ini hanya secara umum sehingga tidak mengupas lebih dalam mengenai seberapa besar dampak atau impact motion comic terhadap perilaku lingkungan mengenai gangguan kecemasan sosial.

\section{SIMPULAN}

Hasil review kepada ahli psikologi, ahli komik, guru seni, dan siswa sekolah menengah, menunjukkan bahwa perancangan motion comic mengenai edukasi tentang kepedulian terhadap gangguan kecemasan sosial untuk remaja ini sudah cukup baik. Media motion comic menyampaikan pesan sebagai alat edukasi mengenai gejala gangguan kecemasan sosial yang terjadi di lingkungan remaja, serta sikap kepedulian lingkungan terhadap penderita dan diharapkan dapat menjadi media pembelajaran yang baik sehingga tingkat pemahaman remaja mengenai gangguan kecemasan sosial menjadi lebih baik, agar bisa peduli terhadap sesamanya yang memiliki gejala gangguan kecemasan sosial dan terhindar dari gangguan kecemasan sosial tersebut.

Saran untuk penelitian selanjutnya, diharapkan bisa melakukan pengujian eksperimental di masa mendatang untuk mengetahui tingkat pengetahuan siswa sebelum dan setelah melihat motion comic ini. Penelitian selanjutnya juga dapat menggunakan psikoedukasi konvensional sebagai pembandingnya, sehingga dapat mengetahui bentuk edukasi yang lebih efektif terkait gangguan kecemasan sosial.

\section{DAFTAR PUSTAKA}

Desmita. (2017). Psikologi Perkembangan. Bandung: PT Remaja Rosdakarya.

Durand, V. M. \& Barlow, D. H. (2006). Intisari Psikologi Abnormal. Yogyakarta: Pustaka Pelajar.

Farinella, M. (2018). The Potential of Comics in Science Communication. Journal of Science Communication, 17(01), 1-17. 
Gunawan. (2019). Pembuatan Media Pembelajaran Motion Comic dan Efektivitasnya dalam Penyampaian Materi Akhlak pada Siswa Sekolah dasar. Jurnal Tazkiya, 8(1), 139-156.

Idris, M. Z. (2016). Theoretical Framework and Development Motion Comic Instrument as Teaching Method for History Subject. International Journal of Academic Research in Business and Social Sciences, 6(11), 249-260.

International Design School. (2018). Yuk! Kenalan dengan Berbagai Jenis Font Desain. International Design School. Retrieved from https://idseducation.com/articles/yukkenalan-dengan-berbagai-jenis-fontdesain/

Joshi, S. C. R., Education, B. K. K. P. S. M. C., Road, G., \& Gujarat, P. (2013). Positive Thinking: A Powerful Tool to Reduce Social Anxiety of Under Graduate Students. Paripex-Indian Journal of Research, 2(8), 62-64.

Maharsi, I. (2018). Penciptaan Motion Comic Wayang Beber Jaka Kembang Kuning. Jurnal Dekave, 11(1), 17-23.

Mekuria, K., Mulat, H., Derajew, H., Mekonen, T., Fekadu, W., Belete, A., Yimer, S., Legas, G., Menberu, M., Getnet, A., \& Kibret, S. (2017). High Magnitude of Social Anxiety Disorder in School Adolescents. Psychiatry Journal, 2017, 1-5.

National Center for Biotechnology Information. (2016). DSM-IV to DSM5 social phobia/social anxiety disorder comparison. NCBI. Retrieved from https://www.nc-

bi.nlm.nih.gov/books/NBK519712/tabl e/ch3.t12/

Nevid, J. S., Rathus, S. A., \& Greene, B. (2005). Psikologi abnormal. Jakarta: Erlangga.
Pollack, M. D. \& Mark. (2018). Understanding the unique barriers for people with social anciety disorder. Care for Your Mind. Retrieved from https://careforyourmind.org/under\%0A \%09\%09standing-the-unique-barriers-forpeople-withsocial-anxietydisorder $/ \% 0 \mathrm{~A}$

Rachmawaty, F. (2015). Peran Pola Asuh Orang Tua terhadap Kecemasan Sosial pada Remaja. Jurnal Psikologi Tabularasa. 10(1), 31-42.

Ratnani, I., Vala, A., Panchal, B., Tiwari, D., Karambelkar, S., Sojitra, M., \& Nagori, N. (2017). Association of Social Anxiety Disorder with Depression and Quality of Life among Medical Undergraduate Students. Journal of Family Medicine and Primary Care, 6(2), 243-248.

Saman, A., Aryani, F., \& Bakhtiar, M. I. (2017). Mengatasi Kecemasan Sosial melalui Pendekatan Behavioral Rehearsal. Seminar Nasional Dies Natalis Ke 56, 320-326.

Saptodewo, F. (2015). Popularize Puppet Story Among Young Generation. Jurnal Desain, 2(3), 145-156.

Sarwono, J. (2007). Metode riset untuk desain komunikasi visual. Yogyakarta: Andi.

Schoonenboom, J., \& Johnson, R. B. (2017). Wie man ein Mixed MethodsForschungs-Design konstruiert. Kolner Zeitschrift Fur Soziologie Und Sozialpsychologie, 69, 107-131. doi: 10.1007/s11577-017-0454-1.

Tiffany. (2017). Fobia Sosial - Pengertian, Gejala, dan Cara Mengatasinya. Dosen Psikologi.com. Retrieved from https://dosenpsikologi.com/fobiasosial/

Willis, L. A., Kachur, R., Castellanos, T. J., Spikes, P., Gaul, Z. J., Gamayo, A. C., Durham, M., Jones, S., Nichols, K., 
Barthelemy, S. H., LaPlace, L., Staatz, C., Hogben, M., Robinson, S., Brooks, J. T., \& Sutton, M. Y. (2018). Developing a Motion Comic for
HIV/STD Prevention for Young People Ages 15-24, Part 1: Listening to Your Target Audience. Journal Health Communication, 33(2), 212-221. 